\title{
Does parental heart rate affect embryonic heart rate during incubation? An experiment in Common Terns Sterna hirundo
}

\author{
Nathalie Kürten $^{1,2} \mathbb{D} \cdot$ Kristin Piening $^{1,2} \cdot$ Oscar Vedder $^{1} \mathbb{D}$
}

Received: 11 November 2020 / Revised: 11 February 2021 / Accepted: 23 February 2021 / Published online: 12 March 2021

(c) The Author(s) 2021

\begin{abstract}
Embryonic heart rate is a strong determinant of metabolic rate and the rate of embryonic development in oviparous species. In humans, embryonic heart rate is positively correlated with the heart rate of the mother. However, human embryos do not develop autonomously from the maternal circulatory system, making it impossible to separate maternal control from an independent embryonic adjustment of its heart rate to that of its mother. In birds, embryonic development does occur autonomously from the mother, while the embryo can auditively perceive the heart rate of the incubating parent. In this study, we used Common Terns (Sterna hirundo) to experimentally test whether the embryonic heart rate is affected by parental heart rate during incubation. We artificially incubated freshly laid eggs under standardized conditions and continuously exposed them to the sound of either a slow or fast parental heart rate throughout the first 18 days of embryonic development. At day 18 of embryonic development (a few days before hatching) there was no significant difference in the embryonic heart rate between both treatments. There was also no effect of treatment on either total duration of embryonic development or hatching success. We suggest that embryonic heart rate and development rate may not be affected by the heart rate of the parent because natural parental heart rates are very sensitive to external conditions that may fluctuate drastically, while embryos may need a relatively stable heart rate for optimal development.
\end{abstract}

Keywords Acoustic stimulation · Maternal effect · Parent-offspring coadaptation · Parent-offspring communication · Prenatal development

\section{Zusammenfassung}

Beeinflusst die elterliche Herzfrequenz die embryonale Herzfrequenz während der Inkubation? Ein Experiment an Flussseeschwalben

Die embryonale Herzfrequenz ist ein bestimmender Faktor für die Stoffwechselrate und die embryonale Entwicklungsgeschwindigkeit bei oviparen Arten. Bei Menschen korreliert die embryonale Herzfrequenz positiv mit der Herzfrequenz der Mutter. Dennoch entwickeln sich menschliche Embryos nicht autonom vom mütterlichen Kreislaufsystem, was es unmöglich macht die mütterliche Kontrolle von der unabhängigen embryonalen Anpassung ihrer Herzfrequenz an die ihrer Mutter zu trennen. Bei Vögeln hingegen findet die embryonale Entwicklung unabhängig von der Mutter statt, obwohl der Embryo die Herzfrequenz des inkubierenden Elternteils akustisch wahrnehmen kann. In der vorliegenden Studie untersuchten wir an Flussseeschwalben (Sterna hirundo), ob die embryonale Herzfrequenz von der ihrer Eltern während der Inkubation beeinflusst wird. Dazu inkubierten wir frisch gelegte Eier künstlich unter standardisierten Bedingungen, und

Communicated by I. Moore.

Nathalie Kürten and Kristin Piening share first-authorship.

Oscar Vedder

oscar.vedder@ifv-vogelwarte.de

1 Institute of Avian Research, An der Vogelwarte 21, 26386 Wilhelmshaven, Germany

2 University of Oldenburg, 26111 Oldenburg, Germany 
setzten diese kontinuierlich entweder dem Sound einer langsamen oder schnellen Herzfrequenz während der ersten 18 Tage der embryonalen Entwicklung aus. Am 18. Tag der embryonalen Entwicklung (ein paar Tage vor dem Schlupf) war kein signifikanter Unterschied zwischen den beiden Verfahren festzustellen. Zudem gab es weder einen Effekt der beiden Verfahren auf die Gesamtinkubationszeit noch auf den Schlupferfolg. Wir nehmen daher an, dass die embryonale Herzfrequenz und die embryonale Entwicklungsgeschwindigkeit nicht von der Herzfrequenz der Eltern beeinflusst werden, weil die natürlichen elterlichen Herzfrequenzen sensibel gegenüber äußeren Einflüssen sind, welche drastisch schwanken können, während Embryos eine relativ stabile Herzfrequenz für ihre optimale Entwicklung benötigen.

\section{Introduction}

An individual's heart rate is the speed of the heartbeat measured by the number of contractions (beats) of the heart muscle per minute (bpm). With a heartbeat, blood is pumped through the circulatory system to supply all regions of the body with nutrients and oxygen. As such, an individual's metabolic rate is a direct function of its heart rate, as well as the stroke volume and the oxygen content of the blood (Butler et al. 2004). In oviparous species, embryos with faster heart rates also develop faster, confirming that heart rate is a major component of the response of the embryo to an increase in the demand for oxygen and nutrients that comes with faster embryonic development (Du et al. 2009; Vedder et al. 2017).

Interestingly, despite the human embryo having a much faster heart rate than the mother, there is a strong positive correlation between embryonic and maternal heart rate in humans (Patrick et al. 1982). Focusing on short phases of embryonic-maternal heart rate synchronization, a study in humans suggests that the embryonic circulatory system might be able to react to the maternal heart rate (Van Leeuwen et al. 2009). This phenomenon also appears to be present in rats (Rattus norvegicus; Timofeeva et al. 2015). In placental mammals, however, the embryo is provided with maternal hormones, nutrients, and oxygen via the placenta (Knipp et al. 1999), providing the opportunity for the mother to directly tune embryonic heart rate, instead of the embryo reacting autonomously to the mother.

In birds, the embryo receives its oxygen from the atmosphere through the porous eggshell (Tazawa 2005), while the nutrients it requires until hatching are provided by the albumen and the yolk in the egg (Lovette and Fitzpatrick 2016). Nevertheless, during embryonic development via natural incubation, the heart rate of the incubating parent represents one of the clearest sounds the embryo can perceive (Arnold et al. 2011; Borneman et al. 2014) and studies suggest that avian embryos can react to auditory cues from their environment (Colombelli-Négrel et al. 2012; Mariette and Buchanan 2016; Noguera and Velando 2019). We, therefore, aimed to test if avian embryos autonomously adjust their heart rate to that of their parents, which, to our knowledge, has hitherto never been done. Such heart rate adjustments could act as a mechanism behind family-transmitted stress, which under certain conditions may be adaptive in birds (Noguera et al. 2017).

To this aim, we artificially incubated freshly laid eggs from wild Common Terns (Sterna hirundo), and randomly exposed them to the sound of either a slow or fast parental heart rate, throughout the majority of embryonic development. We subsequently tested whether embryonic heart rate during late embryonic development differed between the parental heart rate treatments and whether this had consequences for the rate of embryonic development. We predicted that, if embryos adjust their heart rate to that of their parents, the fast parental heart rate treatment would lead to a faster embryonic heart rate and a shorter total incubation duration.

\section{Methods}

\section{Study species and site}

Common terns are socially and genetically monogamous colonially breeding seabirds (Becker and Ludwigs 2004). Incubation starts after the first egg is laid and is shared between the sexes (Becker and Ludwigs 2004). The clutch usually consists of 2-3 eggs laid at intervals of 1-2 days, and the chicks generally hatch after 21-23 days, in the order of laying (Nisbet and Cohen 1975; Becker and Ludwigs 2004).

We studied Common Terns breeding at the Banter See in the city of Wilhelmshaven, at the German North Sea coast $\left(53^{\circ} 30^{\prime} 40^{\prime \prime} \mathrm{N}, 08^{\circ} 06^{\prime} 20^{\prime \prime} \mathrm{E}\right)$. This breeding site consists of six concrete islands each measuring $10.7 \times 4.6 \mathrm{~m}$ with $60 \mathrm{~cm}$ high concrete walls protecting against flooding and predation. In recent years, the colony size is ca. $650-700$ breeding pairs per year.

\section{Audio recording and processing}

To obtain the sound of the heart rate of an incubating adult Common Tern, we placed a microphone (electret capacitor microphone capsule MCE 101; Reichelt Elektronik GmbH \& Co. KG, Germany) in a fake egg, which was connected to a digital audio recorder (following Arnold et al. 2011). The egg was placed in the nest for 20-30 min to record the heart 
rate of the incubating parent. We made recordings of several individuals, always early in the morning (5-7 am; as the birds incubate most solidly at this time), but only selected the best recording to modify with the audio program Audacity (version 2.3.2, Audacity Team 2019).

We eliminated background noises in the recording by the use of a low pass filter while preserving heartbeats. We chose a sample rate of $11,025 \mathrm{~Hz}$ to reduce the maximum noise and normalized the loudest one at $-1 \mathrm{~dB}$. To create a new audio track of the bird's heartbeat, we chose one clear clip of a single heartbeat, and attenuated noise of less than $50 \mathrm{~Hz}$ and above $800 \mathrm{~Hz}$. By repeating the single heartbeat with a modified inter-beat interval, we created two stable heart rates that varied in inter-beat interval but were otherwise identical. In this way, we created a slow heart rate of 300 beats per minute (bpm) and a faster heart rate of $340 \mathrm{bpm}$. We chose these values to obtain heart rates within the known heart rate range of Common Tern embryos at $37.5^{\circ} \mathrm{C}$ (mean $=301, \mathrm{SD}=23$, range $=240-372 \mathrm{bpm}$; Vedder et al. 2017) and parents (range $=173-525 \mathrm{bpm}$; Wurm 1996; Wurm and Hüppop 1998). We used two semi-artificially created heart rates, instead of separate recordings of a natural fast and slow heart rate, to ensure that the heart rates only differed in inter-beat interval and not in any other characteristic that may provide information to the embryo.

\section{Data collection and experimental setup}

In the breeding season of 2020 , we performed twice-daily checks (mornings and afternoons) of the colony site to mark new clutches at the day of first-egg laying. We collected 91 eggs of 35 clutches on the day of laying, which we numbered according to clutch identity and laying order. We replaced the eggs with fake eggs, which were roughly similar in size and colour, and readily accepted by the parents.

After collection, we assigned eggs to one of two incubation treatments. The first egg of a clutch was randomly assigned to a treatment, while the second egg of a clutch (if present) was always assigned to the opposite treatment of the first egg, and the third egg (if present) assigned to the same treatment as the first egg of the clutch. In this way, we assured that eggs of the same clutch were distributed across the two treatments. Both treatments consisted of artificial incubation (starting within $1 \mathrm{~h}$ of egg collection) in a digital air-filled incubator (Rcom max 50; Autoelex Cp., Ltd., South Korea) that was set at $37.5^{\circ} \mathrm{C}$ with a relative humidity of 50\% (following Vedder et al. 2017). For the different treatments, we used two identical incubators with identical settings, in which we either played a continuous soundtrack of the $300 \mathrm{bpm}$ parental heart rate, or that of the $340 \mathrm{bpm}$ parental heart rate. The soundtracks were played with identical sound stations (MusicMan Mini Soundstation; Technaxx Deutschland GmbH \& Co. KG; Germany) mounted inside the incubators. Once per hour both incubators automatically turned the eggs ca. $90^{\circ}$. To avoid potential temperature gradients in the incubator affecting the eggs, egg positions were manually and randomly changed once per day. The overall hatching success was $84.6 \%$, and not significantly different between the treatments ( $300 \mathrm{bpm}: 80.4 \%$ vs. $340 \mathrm{bpm}$ : $88.9 \%, \chi^{2}=1.22, \Delta d f=1, P=0.269$ ).

We measured the embryonic heart rate of each viable egg 18 days after the onset of incubation (before pipping of the inner shell membrane by the embryo) with a digital egg monitoring system (Buddy; Avitronics, Truro, United Kingdom), which uses infrared sensors to detect the pulse of a blood vessel. We conducted the heart rate measurements outside of the incubator at room temperature. We recorded the first stable heart rate (in bpm) and the time it took before the heart rate was stable (in s). The latter measure was taken because the embryonic heart rate decreases when an egg cools off (Sheldon et al. 2018). If the heart rate did not stabilize within $3 \mathrm{~min}$, the egg was returned to the incubator and the process repeated after a minimum interval of one hour. The mean time it took before the heart rate was stable was $69 \mathrm{~s}(\mathrm{SD}=49$, range $=6-174 \mathrm{~s})$. We previously showed that embryonic heart rate at 18 days was positively correlated with embryonic heart rate at 19 days, and predictive of total embryonic development time in Common Terns (Vedder et al. 2017). After the measurement, all eggs were transferred to a hatching incubator (Rcom max 50; Autoelex Cp., Ltd., South Korea) with a temperature of $37.0^{\circ} \mathrm{C}$ and relative humidity of $60 \%$, with no egg turning.

In the hatching incubator, the eggs were placed in separate compartments divided by wire mesh to allow linking each hatchling to its egg. A digital camera was programmed to take a picture of the content of the hatching incubator every half hour. These pictures were manually scored for the hatching of chicks, defined as the head being completely out of the egg, and the total incubation duration of each chick was calculated by subtracting the time of onset of artificial incubation from the time a chick was first recorded as hatched (in days, with a resolution of $30 \mathrm{~min}$ ). After hatching, chicks were ringed and returned to their nest of origin within half a day. All parents readily accepted their chicks upon return. The fake eggs were removed from the nest when chicks were returned, or 1-2 days after the last chick was returned in case not all eggs from a clutch hatched.

\section{Statistical analyses}

The effect of the parental heart rate treatment (as a categorical fixed effect) on embryonic heart rate on day 18 and the total incubation duration was analyzed at the level of the individual embryo using linear mixed models with normal error distributions that included clutch identity as a random effect, to account for the non-independence of embryos 
within clutches (Vedder et al. 2017). The effect of embryonic heart rate, and its interaction with treatment, on total incubation duration, was analyzed in the same way. For the test of a treatment effect on embryonic heart rate, we included the time until a stable heart rate was recorded in the model as a covariate, to correct for the cooling of the embryo at room temperature.

The effect of the treatment (as a categorical fixed effect) on hatching success, reported above, was analyzed using a generalized linear mixed model with a binomial error distribution and a logit link function. Clutch identity was included as a random effect.

All models were run in MLwiN (version 2.22; Rasbash et al. 2004) and significance $(P<0.05)$ was assessed using the Wald statistic.

\section{Results}

Exposure to the sound of a faster parental heart rate did not lead to a faster embryonic heart rate, as the embryonic heart rate on day 18 of incubation did not differ significantly between the two treatments (Fig. 1; Table 1a).

A faster parental heart rate also did not lead to faster embryonic development, as the total incubation duration of successfully hatched chicks did not differ significantly between the two treatments (Fig. 2; Table 1b).

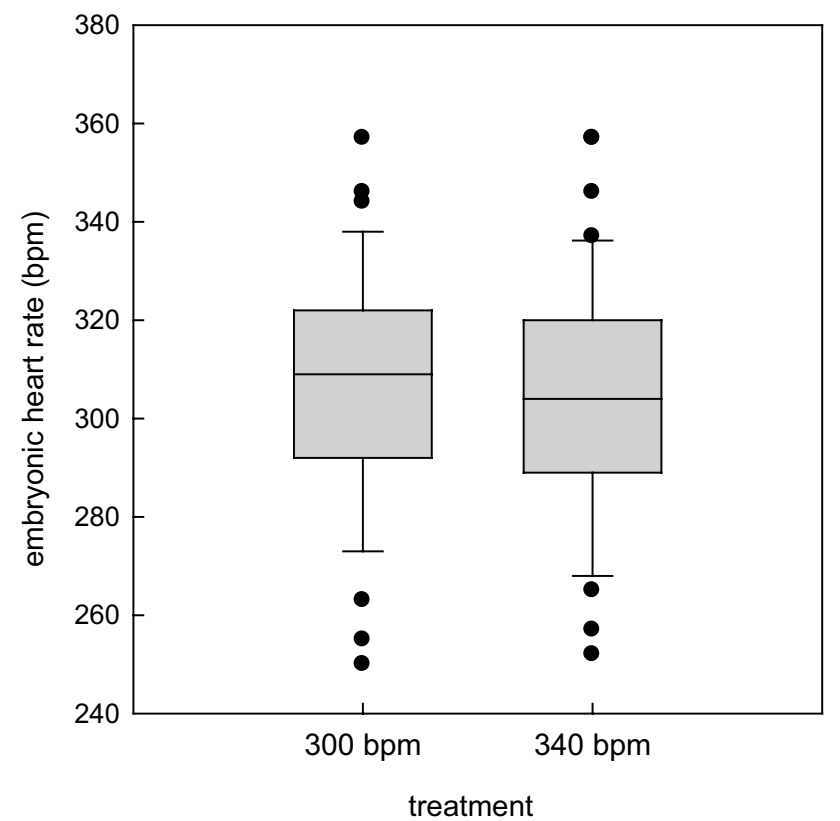

Fig. 1 Boxplots (showing the median, interquartile range, 10th and 90th percentile, and individual data points outside this range) of embryonic heart rate (bpm) at day 18 of incubation for the two different parental heart rate treatments $(n=39$ eggs from 30 clutches for $300 \mathrm{bpm}, n=43$ eggs from 33 clutches for $340 \mathrm{bpm}$ )
Table 1 Summary of models testing for effects of the parental heart rate treatment on embryonic heart rate (a) and total incubation duration (b)

\begin{tabular}{|c|c|c|c|c|}
\hline Model & Coefficient (SE) & $\chi^{2}$ & $\Delta d f$ & $P$ \\
\hline \multicolumn{5}{|c|}{ (a) Dependent variable: embryonic heart rate (bpm) } \\
\hline Intercept & $317.79(5.44)$ & & & \\
\hline Clutch ID (random) & $213.38(86.86)$ & 6.04 & 1 & 0.014 \\
\hline Time until stable heart rate $(\mathrm{s})$ & $-0.15(0.05)$ & 9.27 & 1 & 0.002 \\
\hline Treatment $(300 \mathrm{bpm}=\mathrm{ref})$ & $-6.13(4.18)$ & 2.16 & 1 & 0.142 \\
\hline \multicolumn{5}{|c|}{ (b) Dependent variable: total incubation duration (day) } \\
\hline Intercept & $21.48(0.08)$ & & & \\
\hline Clutch ID (random) & $0.06(0.04)$ & 3.16 & 1 & 0.075 \\
\hline Treatment $(300 \mathrm{bpm}=$ ref $)$ & $0.10(0.09)$ & 1.17 & 1 & 0.279 \\
\hline
\end{tabular}

As found previously (Vedder et al. 2017), total incubation duration was shorter with a faster embryonic heart rate (Fig. 3; coefficient $\pm \mathrm{SE}=-0.010 \pm 0.002$ day/bpm, $\left.\chi^{2}=24.10, \Delta d f=1, P<0.001\right)$. This effect was not significantly different between treatments (heart rate $\times$ treatment interaction: coefficient $\pm \mathrm{SE}=-0.003 \pm 0.004 \mathrm{day} / \mathrm{bpm}$, $\chi^{2}=0.46, \Delta d f=1, P=0.499$ ).

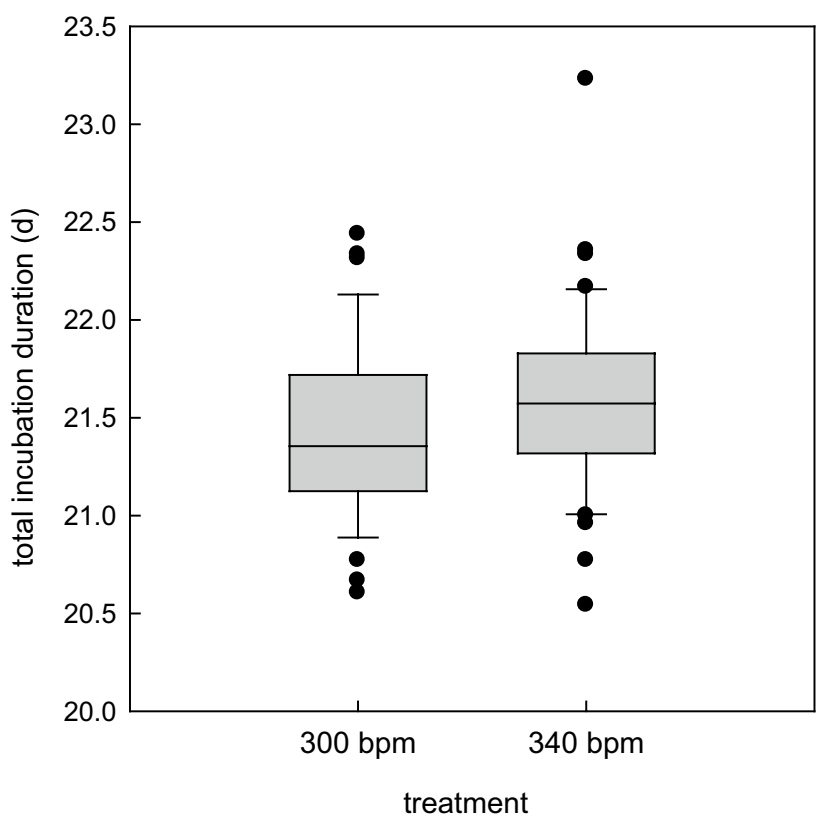

Fig. 2 Boxplots (showing the median, interquartile range, 10th and 90th percentile, and individual data points outside this range) of total incubation duration (day) for the two different parental heart rate treatments $(n=37$ eggs from 29 clutches for $300 \mathrm{bpm}, n=40$ eggs from 30 clutches for $340 \mathrm{bpm}$ ) 


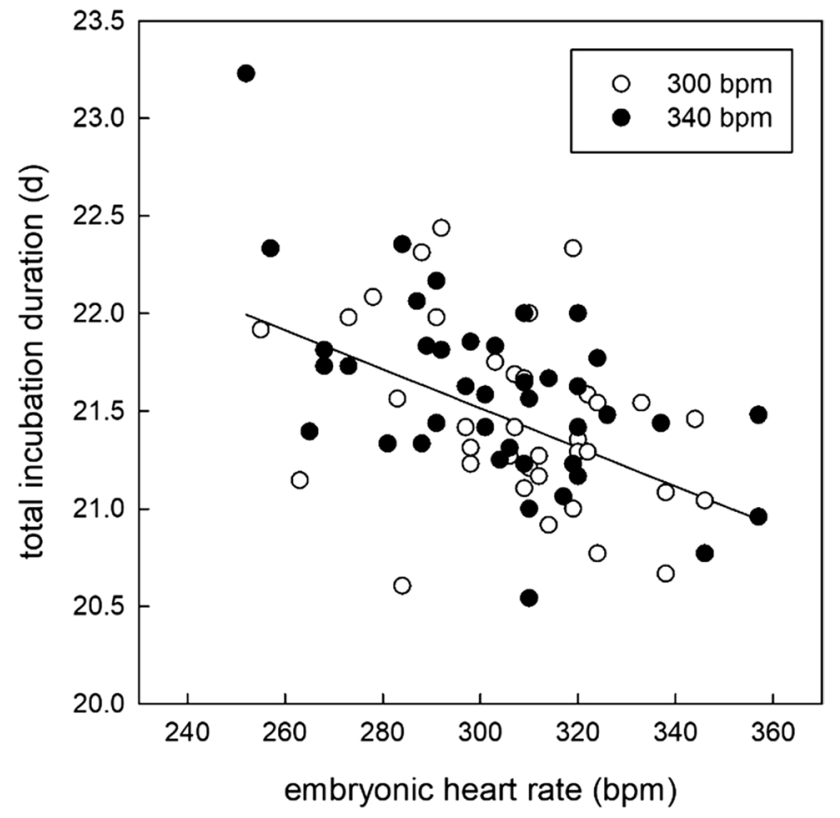

Fig. 3 Total incubation duration (day) plotted against embryonic heart rate (bpm) at day 18 for the two different parental heart rate treatments. The trend line represents the overall model prediction

\section{Discussion}

By artificial incubation of freshly laid eggs, we were able to measure the embryonic heart rate on day 18 of incubation and the total incubation duration under standardized conditions that only differed in the speed of the parental heart rate the embryos were auditorily exposed to. Although we did not find that Common Terns embryos adjust their heart rate and speed of development to the speed of the experimental parental heart rate in this study, this was, to our knowledge, the first experimental test of whether the heart rate of avian embryos is sensitive to the heart rate of their parents.

Other studies have suggested that embryonic heart rate in birds is sensitive to environmental conditions (Sheldon et al. 2018), in particular to temperature (Vedder et al. 2017; Sheldon et al. 2018; Stier et al. 2020). Indeed, we found a decrease in embryonic heart rate as egg temperature declined during the measurement at room temperature (see Table 1a). Hence, the lack of an effect of parental heart rate in our study does not stem from a general insensitivity of embryonic heart rate to the environment but reflects a specific insensitivity to the parental heart rate.

Mechanistically, the observed lack of a response may be explained by a lack of perception of the parental heart rate. Analysis of the avian embryo sensory system revealed that auditory perception develops at a late stage (Gottlieb 1968). However, in the Chicken (Gallus domesticus), which has a similar embryonic development time as Common Terns, it was found that hearing begins on day 16 of embryonic development (Jones et al. 2006). In semi-precocial species, which include the Common Tern, hearing generally develops in the last third of incubation (Golubeva and Tikhonov 1985). As day 18 is well into the last third of incubation in Common Terns, we do not deem a lack of perception to be the most likely explanation for the lack of an effect. However, we cannot rule out that our semi-artificial parental heart rates do not provide the correct stimulus for the embryo, because they will be more monotonous than natural. In our incubation set-up, there is also no direct contact between the parent and egg shell, which could make it more difficult for the embryo to perceive the vibrations of the parental heart rate.

Alternatively, from a functional perspective, it may not be adaptive for the embryo to adjust its heart rate to that of its parents. In general, the heart rate of incubating birds can be extremely dynamic (Odum 1941). This is also found in Common Terns, in which ambient temperature and disturbance of the parents can have a large effect on parental heart rate during incubation (Wurm 1996; Wurm and Hüppop 1998). Adjusting the embryonic heart rate to such a dynamic cue may disturb embryonic development and reduce embryo viability. As such, it may be adaptive to adjust embryonic heart rate to the external energy the parent supplies during incubation (i.e., to incubation temperature), but not to dynamic environmental cues.

In conclusion, our experimental results do not suggest that embryonic heart rate and development rate are affected by the heart rate of the parent in Common Terns. Although we cannot rule out that our experiment did not provide the right stimulus, we suggest that embryos do not adjust their heart rate to their parent's because it may not be adaptive for them to do so.

Acknowledgements We would like to thank Sandra Bouwhuis for facilitating our work in the Common Tern colony and providing useful feedback on the manuscript, Miriam Liedvogel and two anonymous reviewers for feedback on the manuscript, Timo Ubben for technical support and Ommo Hüppop for providing valuable insights into the dynamics of avian heart rates.

Funding Open Access funding enabled and organized by Projekt DEAL.

Data availability Data will be available upon request to the corresponding author.

\section{Declarations}

Conflicts of interest We declare no conflicts of interest.

Ethics approval All procedures complied with current German law. 
Open Access This article is licensed under a Creative Commons Attribution 4.0 International License, which permits use, sharing, adaptation, distribution and reproduction in any medium or format, as long as you give appropriate credit to the original author(s) and the source, provide a link to the Creative Commons licence, and indicate if changes were made. The images or other third party material in this article are included in the article's Creative Commons licence, unless indicated otherwise in a credit line to the material. If material is not included in the article's Creative Commons licence and your intended use is not permitted by statutory regulation or exceeds the permitted use, you will need to obtain permission directly from the copyright holder. To view a copy of this licence, visit http://creativecommons.org/licenses/by/4.0/.

\section{References}

Arnold JM, Ordonez R, Copeland DA, Nathan R, Scornavacchi JM, Tyerman DJ, Oswald SA (2011) Simple and inexpensive devices to measure heart rates of incubating birds. J Field Ornithol 82:288-296. https://doi.org/10.1111/j.1557-9263.2011.00332.x

Audacity Team (2019) Audacity(R): free audio editor and recorder [computer application]. Version 2.3.2. http://web.audacityte am.org/download. Accessed 13 Nov 2019

Becker PH, Ludwigs J-D (2004) Sterna hirundo common tern. In: Parkin D (ed) BWP update nos 1/2, vol 6. Oxford University Press, New York, pp 93-139

Borneman TE, Rose ET, Simons TR (2014) Minimal changes in heart rate of incubating American oystercatchers (Haematopus palliatus) in response to human activity. Condor 116:493-503. https:// www.jstor.org/stable/90008470

Butler PJ, Green JA, Boyd IL, Speakman JR (2004) Measuring metabolic rate in the field: the pros and cons of the doubly labelled water and heart rate methods. Funct Ecol 18:168-183. https://doi. org/10.1111/j.0269-8463.2004.00821.x

Colombelli-Négrel D, Hauber ME, Robertson J, Sulloway FJ, Hoi H, Griggio M, Kleindorfer S (2012) Embryonic learning of vocal passwords in superb fairy-wrens reveals intruder cuckoo nestlings. Curr Biol 22:2155-2160. https://doi.org/10.1016/j. cub.2012.09.025

Du W-G, Radder RS, Sun B, Shine R (2009) Determinants of incubation period: do reptilian embryos hatch after a fixed total number of heart beats? J Exp Biol 212:1302-1306. https://doi. org/10.1242/jeb.027425

Golubeva TB, Tikhonov AV (1985) The voice and hearing of birds in ontogeny. In: Gavrilov VM, Ilyichev VD (eds) Acta XVIII Internat Ornithol. Congr Nauka, Moscow, pp 259-274

Gottlieb G (1968) Prenatal behaviour of birds. Q Rev Biol 43:148-174. https://doi.org/10.1086/405726

Jones TA, Jones SM, Paggett KC (2006) Emergence of hearing in the chicken embryo. J Neurophysiol 96:128-141. https://doi. org/10.1152/jn.00599.2005

Knipp GT, Audus KL, Soares MJ (1999) Nutrient transport across the placenta. Adv Drug Deliv Rev 38:41-58. https://doi.org/10.1016/ s0169-409x(99)00005-8

Lovette IJ, Fitzpatrick JW (2016) Handbook of bird biology. Wiley, Oxford

Mariette MM, Buchanan KL (2016) Prenatal acoustic communication programs offspring for high posthatching temperatures in a songbird. Science 353:812-814. https://doi.org/10.1126/scien ce.aaf7049

Nisbet ICT, Cohen ME (1975) Asynchronous hatching in Common and Roseate Terns, Sterna hirundo and S. dougallii. Ibis 117:374-379. https://doi.org/10.1111/j.1474-919X.1975.tb04225.x

Noguera JC, Velando A (2019) Bird embryos perceive vibratory cues of predation risk from clutch mates. Nat Ecol Evol 3:1225-1232. https://doi.org/10.1038/s41559-019-0929-8

Noguera JC, Kim SY, Velando A (2017) Family-transmitted stress in a wild bird. Proc Natl Acad Sci USA 114:6794-6799. https://doi. org/10.1073/pnas.1706164114

Odum EP (1941) Variations in the heart rate of birds: a study in physiological ecology. Ecol Monogr 11:299-326. https://doi. org/10.2307/1943206

Patrick J, Campbell K, Carmichael L, Probert C (1982) Influence of maternal heart rate and gross fetal body movements on the daily pattern of fetal heart rate near term. Am J Obstet Gynecol 144:533-538. https://doi.org/10.1016/0002-9378(82)90222-8

Rasbash JF, Steele F, Browne W, Prosser B (2004) A user's guide to MLwiN, version 2.0. Centre for Multilevel Modelling, London

Sheldon EL, McCowan LS, McDiarmid CS, Griffith SC (2018) Measuring the embryonic heart rate of wild birds: an opportunity to take the pulse on early development. Auk 135:71-82. https://doi. org/10.1642/AUK-17-111.1

Stier A, Metcalfe NB, Monaghan P (2020) Pace and stability of embryonic development affect telomere dynamics: an experimental study in a precocial bird model. Proc R Soc B 287:20201378. https://doi.org/10.1098/rspb.2020.1378

Tazawa H (2005) Cardiac rhythms in avian embryos and hatchlings. Avian Poult Biol Rev 16:123-150. https://doi.org/10.3184/14702 0605783437977

Timofeeva OP, Vdovichenko ND, Bursian AV (2015) Quantitative assessment of the relationship of slow-wave heart rate oscillations and motor activity in rat fetuses with maternal respiratory and cardiac activity. J Evol Biochem Phys 51:412-420. https:// doi.org/10.1134/S0022093015050075

Van Leeuwen P, Geue D, Thiel M, Cysarz D, Lange S, Romano MC, Wessel N, Kurths J, Grönemeyer DH (2009) Influence of paced maternal breathing on fetal-maternal heart rate coordination. Proc Natl Acad Sci USA 106:13661-13666. https://doi.org/10.1073/ pnas.0901049106

Vedder O, Kürten N, Bouwhuis S (2017) Intraspecific variation in, and environment-dependent resource allocation to, embryonic development time in common terns. Physiol Biochem Zool 90:453460. https://doi.org/10.1086/691690

Wurm S (1996) Auswirkungen akustischer reize auf die herzschlagrate brütender flußseeschwalben (Sterna hirundo). Diploma thesis, University of Göttingen

Wurm S, Hüppop O (1998) Reaktion der herzschlagrate von flußseeschwalben (Sterna hirundo) auf das angebot akustischer reize. Seevögel 19:92-95

Publisher's Note Springer Nature remains neutral with regard to jurisdictional claims in published maps and institutional affiliations. 